\title{
Emerging concepts in ventilation-induced lung injury [version
}

\section{1; peer review: 4 approved]}

\author{
Purnema Madahar1-3, Jeremy R. Beitler (Di) 1-3
}

${ }^{1}$ Center for Acute Respiratory Failure, Columbia University College of Physicians and Surgeons, New York City, NY, USA

${ }^{2}$ Division of Pulmonary, Allergy, and Critical Care Medicine, Columbia University College of Physicians and Surgeons, New York City, NY, USA

${ }^{3}$ Department of Medicine, New York-Presbyterian Hospital, New York City, NY, USA

V1 First published: 31 Mar 2020, 9(F1000 Faculty Rev):222

https://doi.org/10.12688/f1000research.20576.1

Latest published: 31 Mar 2020, 9(F1000 Faculty Rev):222

https://doi.org/10.12688/f1000research.20576.1

\begin{abstract}
Ventilation-induced lung injury results from mechanical stress and strain that occur during tidal ventilation in the susceptible lung. Classical descriptions of ventilation-induced lung injury have focused on harm from positive pressure ventilation. However, injurious forces also can be generated by patient effort and patient-ventilator interactions. While the role of global mechanics has long been recognized, regional mechanical heterogeneity within the lungs also appears to be an important factor propagating clinically significant lung injury. The resulting clinical phenotype includes worsening lung injury and a systemic inflammatory response that drives extrapulmonary organ failures. Bedside recognition of ventilationinduced lung injury requires a high degree of clinical acuity given its indistinct presentation and lack of definitive diagnostics. Yet the clinical importance of ventilation-induced lung injury is clear. Preventing such biophysical injury remains the most effective management strategy to decrease morbidity and mortality in patients with acute respiratory distress syndrome and likely benefits others at risk.
\end{abstract}

\section{Keywords}

ventilator-induced lung injury, acute respiratory distress syndrome, acute lung injury, respiratory mechanics, mechanical ventilation

\section{Open Peer Review

$\begin{array}{rrrr}\text { Approval Status } & \\ 1 & 2 & 3 & 4\end{array}$ \\ version 1 \\ 31 Mar 2020 \\ Faculty Reviews are review articles written by the prestigious Members of Faculty Opinions. The articles are commissioned and peer reviewed before publication to ensure that the final, published version is comprehensive and accessible. The reviewers who approved the final version are listed with their names and affiliations.}

1. Jason Bates, University of Vermont, Burlington, USA

2. Nuala J. Meyer, University of Pennsylvania Perelman School of Medicine; Pulmonary, Allergy, and Critical Care Division, Philadelphia, USA

3. Angela Rogers, Stanford University School of Medicine, Stanford, USA

4. Bradford J. Smith, University of Colorado at Children's Hospital Colorado, Aurora, USA

Any comments on the article can be found at the 
end of the article.

Corresponding author: Jeremy R. Beitler (jrb2266@cumc.columbia.edu)

Author roles: Madahar P: Writing - Original Draft Preparation, Writing - Review \& Editing; Beitler JR: Conceptualization, Writing -

Original Draft Preparation, Writing - Review \& Editing

Competing interests: No competing interests were disclosed.

Grant information: Dr. Beitler has received grant support from the U.S. National Heart, Lung, and Blood Institute (K23-HL133489, R21-

HL145506) for research related to this manuscript.

The funders had no role in study design, data collection and analysis, decision to publish, or preparation of the manuscript.

Copyright: @ 2020 Madahar P and Beitler JR. This is an open access article distributed under the terms of the Creative Commons Attribution License, which permits unrestricted use, distribution, and reproduction in any medium, provided the original work is properly cited.

How to cite this article: Madahar $P$ and Beitler JR. Emerging concepts in ventilation-induced lung injury [version 1; peer review: 4 approved] F1000Research 2020, 9(F1000 Faculty Rev):222 https://doi.org/10.12688/f1000research.20576.1

First published: 31 Mar 2020, 9(F1000 Faculty Rev):222 https://doi.org/10.12688/f1000research.20576.1 


\section{Introduction}

Acute respiratory failure often requires mechanical ventilation as a potentially life-saving intervention. However, the development of ventilation-induced lung injury (VILI) is a potentially life-threatening complication. The clinical importance of VILI is clear: limiting tidal volume has been shown definitively in two multicenter randomized trials to improve survival from acute respiratory distress syndrome (ARDS) $)^{1,2}$. Since then, lower tidal volumes have become standard of care for patients with $\mathrm{ARDS}^{3,4}$. Moreover, lower tidal volumes are used increasingly in patients without ARDS $^{5}$, and clinical data suggest benefit in patients at risk of VILI regardless of whether all criteria for ARDS are met $^{6-8}$.

Despite current standard-of-care low tidal volume ventilation, some patients still may experience VILI ${ }^{9-11}$. Limited bedside diagnostic tools impede reliable diagnosis of VILI, and consensus is lacking regarding how best to individualize patient care for prevention and treatment.

The classic schema of VILI describes four central mechanisms: barotrauma, volutrauma, atelectrauma, and biotrauma ${ }^{12}$. Recent preclinical studies and clinical trials have enhanced and refined our understanding of pathophysiology and may help prioritize when interventions offer competing effects on different mechanistic pathways.

This article will provide an updated view of VILI mechanisms, revisit strategies for bedside detection, and provide recommendations for personalized ventilator management to reduce the incidence of VILI guided by available evidence.

\section{Refining the classic schema of VILI mechanisms Barotrauma}

The risk of positive pressure ventilation causing gross barotrauma, pneumothorax, pneumomediastinum, or subcutaneous emphysema, for example, has been recognized for centuries $^{13,14}$. However, most VILI occurs without clinically overt barotrauma. In the classic ARDS Network trial that demonstrated improved survival targeting tidal volumes of 6 compared to $12 \mathrm{~mL} / \mathrm{kg}$ predicted body weight $(\mathrm{PBW})^{2}$, there was no appreciable difference in gross barotrauma (10\% versus $11 \%$ ). For decades preceding ARDSNet, a more occult form of high-pressure injury also termed barotrauma has been recognized. In a classic experiment from Webb and Tierney ${ }^{15}$, anesthetized, tracheotomized rats were ventilated with inspiratory pressures of 14,30 , or $45 \mathrm{cmH}_{2} \mathrm{O}$ for one hour and compared to a control group that did not undergo positive pressure ventilation. The control and low-pressure $\left(14 \mathrm{cmH}_{2} \mathrm{O}\right)$ groups had no evidence of lung injury, whereas those targeting 30 or $45 \mathrm{cmH}_{2} \mathrm{O}$ had increasingly severe histologic injury. Interstitial edema was evident at $30 \mathrm{cmH}_{2} \mathrm{O}$ and both interstitial and alveolar edema at $45 \mathrm{cmH}_{2} \mathrm{O}$. Injury manifested during the experiment as hypoxemia, decreased respiratory compliance, and, in the highest-pressure group, death. Extrapolating these findings to the clinical setting, not only are alveolar edema, hypoxemia, and decreased respiratory compliance hallmarks of ARDS $^{16,17}$ but they can also result directly from VILI. Thus, distinguishing between occult VILI, which may be preventable, and the sequelae of ARDS is exceedingly difficult.

\section{Volutrauma}

The concept of volutrauma, as a potentially distinct form of injury from barotrauma, gained popularity following the report of a classic experiment by Dreyfuss and colleagues ${ }^{18}$. In this study, rats were ventilated with one of three strategies targeting combinations of tidal volume and airway pressure: high-volume/high-pressure, high-volume/low-pressure, and low-volume/high-pressure. The high-volume/low-pressure strategy was achieved with negative pressure ventilation via an iron lung. The low-volume/high-pressure strategy was achieved by placing rubber bands around the thoracoabdominal region to restrict chest wall movement. The study found either strategy with high tidal volumes produced substantial lung injury, demonstrated by extravascular lung water, protein leak, and alveolar cell injury on electron microscopy. By contrast, the low-volume/high-pressure strategy experienced considerably less lung injury by all measures. The authors correctly concluded that "an increase in airway pressure without concomitant increase in lung volume does not produce pulmonary edema". However, this finding has been misinterpreted by many as volutrauma being something different from, and more important than, barotrauma.

\section{Reconciling barotrauma and volutrauma}

Barotrauma and volutrauma arguably describe related aspects of the same phenomenon and can be thought of as mechanical stress and strain, respectively ${ }^{19,20}$. For a deformation of lung shape (strain) to occur, a pressure must be applied (stress). Larger deformations may be injurious (volutrauma) and are generated by higher pressures (barotrauma).

Confusion often arises by misinterpreting airway pressure, which reflects respiratory system mechanics and does not differentiate lung from chest wall contribution ${ }^{21,22}$. Airway pressure is not a reliable indicator of lung parenchymal stress. The pertinent distending pressure of the lungs is the transpulmonary pressure (lung stress), the difference in pressure inside versus outside the lungs, equal to the airway minus pleural pressure ${ }^{23}$. During a breath hold, when airflow and thus flow-resistive pressure are zero, transpulmonary pressure reflects only the elastic recoil of the lungs, often referred to as lung parenchymal stress $^{24}$. In the Dreyfuss experiment ${ }^{18}$, the high-volume/ low-pressure strategy was achieved via negative pressure ventilation, with an iron lung. Thus, while airway pressure was zero (atmospheric) at both end-expiration and end-inspiration, pleural pressure was more negative and transpulmonary pressure was greater at end-inspiration. Thus, the Dreyfuss high-volume/low-airway-pressure strategy is actually a high-volume/high-transpulmonary-pressure strategy. Changes in transpulmonary pressure (but not airway pressure) are concordant: larger changes in volume are accompanied by larger changes in transpulmonary pressure. 


\section{Atelectrauma}

Atelectrauma refers to injury resulting from the cyclic opening and closing of recruitable lung units (small airways extending to alveolar ducts and alveoli) during tidal ventilation ${ }^{25-27}$. In small airways, cyclic opening and closure with each breath generates injurious stress/strain along the airway epithelium as the opening airway takes an "unzippering-like" shape with air bolus propagation (Figure 1) ${ }^{28,29}$. Similar locally high stress/strain may occur from cyclic recruitment/collapse of unstable alveoli that are predisposed to atelectasis because of surfactant inactivation $^{30-32}$. Collapse is likeliest to occur at low end-expiratory lung volumes, when airway and transpulmonary pressures are comparatively lower. In preclinical models, the application of positive end-expiratory pressure (PEEP) to mitigate collapse and maintain higher end-expiratory lung volumes appears to mitigate lung injury ${ }^{25,26,32}$.

However, whether atelectrauma leads to clinically significant lung injury in the modern era is unsettled. Most patients at risk of lung injury are managed with at least modest levels of PEEP in current practice ${ }^{33}$. Clinical trials evaluating more aggressive PEEP strategies have not found a compelling benefit to higher PEEP, when either applied empirically ${ }^{34,35}$ or driven by respiratory mechanics ${ }^{36,37}$.

\section{Alveolar interdependence}

Neighboring alveoli are mechanically interdependent and share an interalveolar septum. In the classic theoretical model proposed by Mead and colleagues ${ }^{23}$, deformation of one alveolus, such as from collapse or being liquid-filled, necessarily causes deformation of the adjacent alveolus, generating high regional tensile forces. This theoretical model has been supported by several studies ${ }^{38-40}$. For example, Perlman and colleagues ${ }^{40}$ used confocal microscopy to visualize neighboring alveoli and then microinfused one alveolus with albumin solution while leaving the others aerated. The liquid-filled alveolus shrunk, taking on the curvature of the meniscus formed at the mouth of the air-liquid interface. This shrinkage of the liquid-filled alveolus caused the interalveolar septum to stretch, bulging into the liquid-filled alveolus and leaving neighboring aerated alveoli deformed and over-expanded (Figure 2). During lung inflation, the adjacent air-filled alveoli became more overdistended and deformed, predisposing to mechanical failure.

Clinical studies have observed greater inflammation in regions of radiographic heterogeneity ${ }^{41}$, thought to be corollary findings to these microscopic observations. This form of VILI, resulting from heterogeneous stress/strain distribution both within individual alveoli and across neighboring alveoli, is described by several synonymous terms in the literature: stress raisers, stress concentration, and lung inhomogeneity, among others ${ }^{42,43}$. The concept, however, again speaks to deformation-induced lung injury. Much like high tidal volumes cause uniformly high stress and strain, mechanical heterogeneity from aerated alveoli adjacent to collapsed or liquid-filled alveoli leads to locally high stress and strain that gets magnified during tidal expansion $^{41,42,44}$.

\section{Patient self-inflicted lung injury}

Re-thinking pressure changes during ventilation in terms of transpulmonary pressures makes it clear that biophysical lung injury may occur in the at-risk patient regardless of whether the ventilator or the patient is generating the pressure ${ }^{45}$. This has led some experts to advocate adopting the term ventilationinduced lung injury or patient self-inflicted lung injury (PSILI) $^{46-48}$. Regardless of terminology, the same basic principles of stress and strain, barotrauma and volutrauma, apply. Two important insights follow when considering patient respiratory
A.

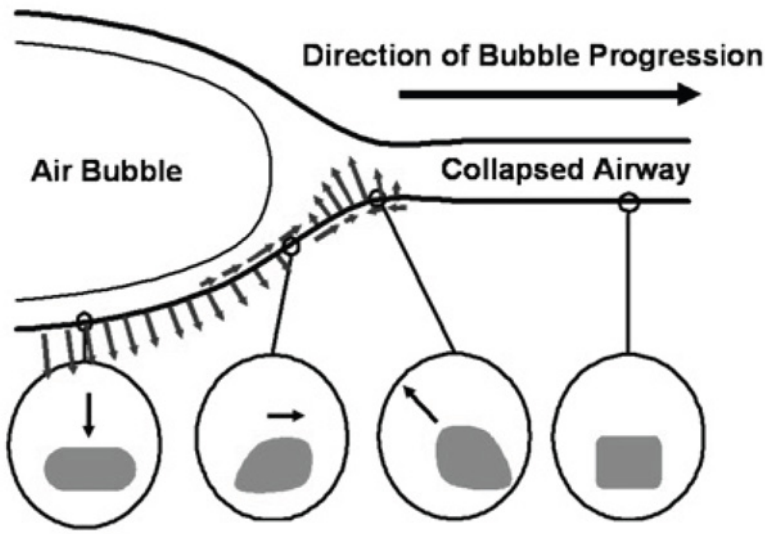

B.

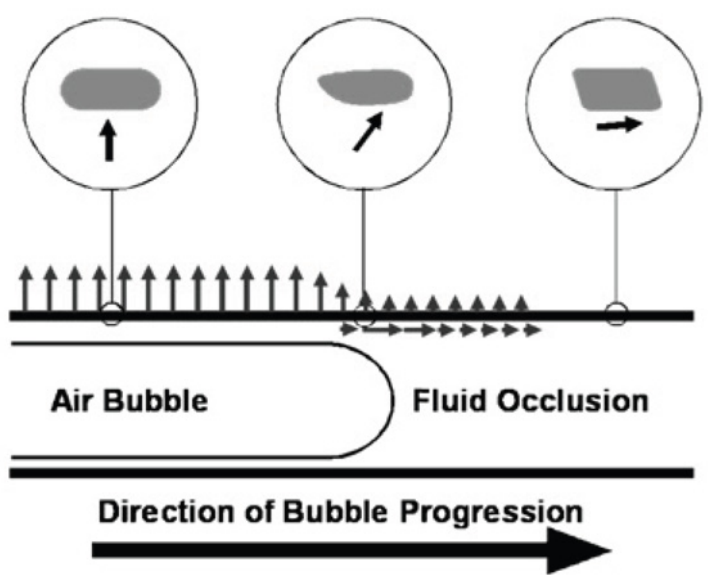

Figure 1. Local stress and strain of epithelial cells generated during recruitment of small airways. (A) Air bubble propagation down the atelectatic airway generates a dynamic wave of stress and strain at the interface of the air bubble and collapsed airway. As the air bubble approaches, the epithelial cell is pulled inward toward the bubble. As the air bubble passes, the cell is pushed outward. (B) The air bubble similarly generates stress and strain of epithelial cells during propagation along flooded airway. This figure was re-used from Ghadiali SN and Gaver DP, Biomechanics of liquid-epithelium interactions in pulmonary airways. Respir Physiol Neurobiol doi:10.1016/j.resp.2008.04.008 with permission ${ }^{28}$. 

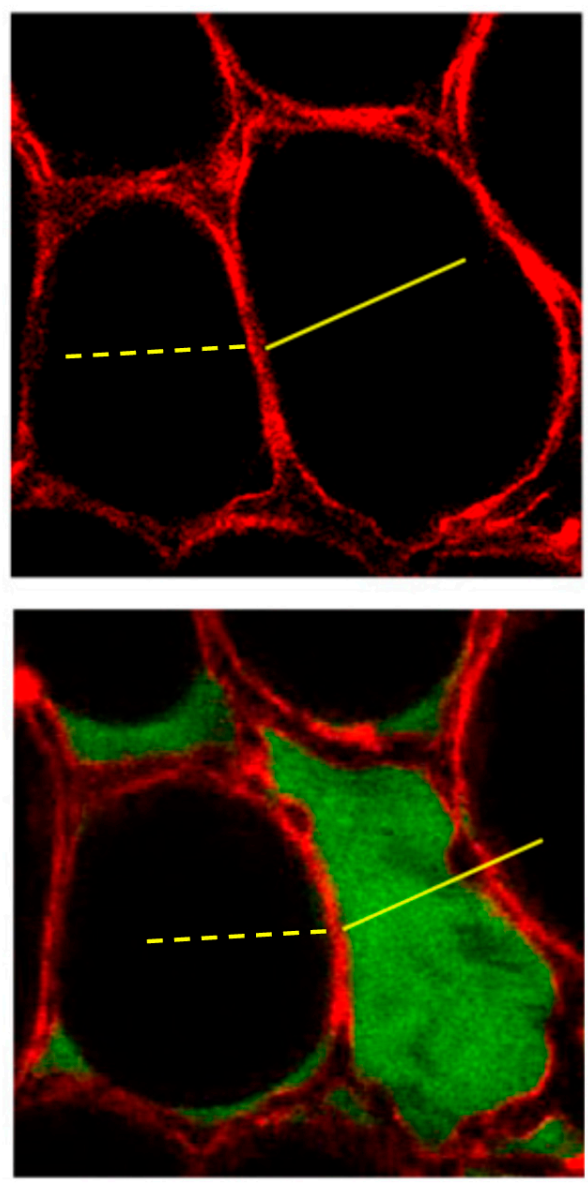

Figure 2. Spatial heterogeneity increases stress and strain due to alveolar interdependence. In the isolated perfused rat lung, confocal microscopy with optical sections $2 \mu \mathrm{m}$ thick permits direct visualization of alveoli. Top: adjacent alveoli share a common septum and are mechanically interdependent. In normal conformation, strain is minimized across neighboring air-filled alveoli. Bottom: in a single-alveolus model of pulmonary edema, the effects on local strain distribution of heterogeneous parenchymal consolidation and flooding can be appreciated. The liquid-filled alveolus shrinks owing to micromechanical effects of meniscus formation. As a result, the adjacent air-filled alveolus bulges and overdistends. This figure was reprinted with permission of the American Thoracic Society. Copyright (C) 2020 American Thoracic Society. Cite: Perlman CE, Lederer DJ, Bhattacharya J. 2011. Micromechanics of alveolar edema. Am J Respir Cell Mol Biol, 44(1), 34-9. The American Journal of Respiratory Cell and Molecular Biology is an official journal of the American Thoracic Society ${ }^{40}$.

effort. One, low airway pressures can be falsely reassuring if forceful inspiratory efforts are made in the mechanically ventilated, spontaneously breathing patient at risk of VILI $^{49,50}$. Two, biophysical injury may occur even in the absence of positive pressure ventilation ${ }^{45}$.

\section{Biotrauma: the final common pathway of VILI}

Biotrauma refers to the biological response to mechanical injury. Regardless of the mechanism of VILI, mechanical cellular injury generates a regional and systemic inflammatory response that further propagates injury ${ }^{51-54}$. Release of damage-associated molecular patterns (DAMPs) in response to mechanical injury promotes the recruitment of immune cells that secrete pro-inflammatory cytokines ${ }^{55}$. Paired with overstretch-induced activation of alveolar epithelial and vascular endothelial cell signaling cascades and dysregulation of the neuroinflammatory reflex ${ }^{56,57}$, a robust systemic inflammatory response results. The repeated cyclic exposure to injurious mechanical forces during tidal ventilation drives this inflammatory process further, which increases alveolar capillary barrier permeability, thereby degrading lung mechanics further and predisposing to additional VILI in a positive feedback loop.

\section{Biotrauma drives morbidity and mortality from VILI}

Morbidity and mortality from VILI are driven primarily by the downstream effects of lung injury on other organs, that is, by biotrauma. In a classic mechanistic clinical trial from Ranieri and colleagues ${ }^{53,58}$, a lower tidal volume strategy attenuated systemic inflammation, and the difference in attenuated inflammation predicted risk of extra-pulmonary organ failures within 72 hours. In the ARDS Network tidal volume trial, lower tidal volumes similarly attenuated systemic inflammation and decreased duration of shock and renal failure, while no improvement in gas exchange over the first few days nor change in gross barotrauma was observed ${ }^{2,59}$. Therefore, protective ventilation against VILI is not only lung protective but also protective against biotrauma-mediated multiple organ failure. This multi-system effect appears to be central to its associated survival benefit.

\section{Monitoring for VILI at bedside}

There remains no strategy for the definitive diagnosis of VILI. Molecular markers of lung injury measured in the blood that are currently used in research, such as soluble receptor for advanced glycation end-products (sRAGE) and surfactant protein D (SP-D), hold potential for use in distinguishing lung injury from cardiogenic edema and prognosticating in ARDS $^{60-62}$, but they may not distinguish mechanical injury (VILI) from other forms of lung injury or ARDS more broadly. Bedside lung and respiratory system mechanics have prognostic value, but their measures do not exhibit a threshold effect for VILI-i.e. no particular numerical cutoff value differentiates VILI risk ${ }^{63-65}$-likely because of the many sources of stress and strain at play simultaneously in the injured lung. Given the association of VILI with biotrauma and multi-organ failure $^{2,53,58,59}$, the patient with concomitant respiratory and extrapulmonary organ failures, and especially distributive shock, should be considered at high risk of VILI. Patients with certain predisposing diagnoses, including pancreatitis, post-esophagectomy, traumatic brain injury, and intracranial hemorrhage, are also classically at high risk ${ }^{8,66,67}$. Recommendations for assessing VILI risk at bedside are reviewed in detail elsewhere ${ }^{43}$.

\section{Monitoring tidal distension}

Classic measures of VILI risk remain central to bedside management, with tidal volume and plateau pressure as surrogates of strain and stress, respectively. However, neither measure offers a data-driven threshold for risk stratification and must be interpreted in the context of a broader clinical assessment. 
In ARDS, the volume of aerated lung is reduced relative to healthy lung size owing to atelectasis and edema, a phenomenon termed "baby lung" ${ }^{68,69}$. Because aerated lung volume is smaller in ARDS, smaller tidal volumes are needed ${ }^{1,2,53}$, but there is no widely accepted strategy for individualizing tidal volume to baby lung size ${ }^{19,64}$. Airway plateau pressure, measured during an end-inspiratory pause, similarly does not account for differences in chest wall mechanics and may reflect elevations in pleural pressure, such as from obesity or a tense abdomen, for example $\mathrm{e}^{22,70,71}$.
Using esophageal manometry to infer pleural pressure and calculate transpulmonary pressure (as airway minus esophageal pressure) may help overcome these limitations (Figure 3) $)^{21,72}$. Esophageal pressure is measured by inserting a thin-walled balloon catheter into the mid-thoracic, retrocardiac esophagus, which positions the balloon approximately in the center of the thoracic cavity. Catheter insertion and interpretation of esophageal pressure are reviewed elsewhere ${ }^{72,73}$. Transpulmonary pressure values, a measure of global lung stress, have intrinsic meaning. For example, a transpulmonary pressure of
A. Lean, not intubated, normal lungs: end-inspiration during normal tidal breathing

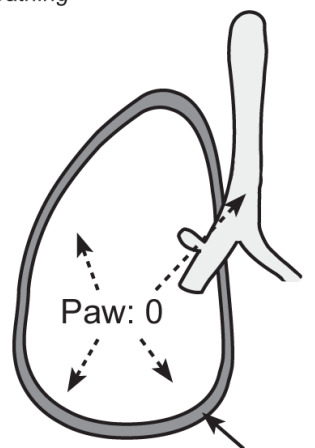

Ppl: -10

Ptp $=0-(-10)=+10 \mathrm{cmH}_{2} \mathrm{O}$

C. Lean, intubated, normal lungs, end-inspiration during positive pressure ventilation after forceful inspiratory effort

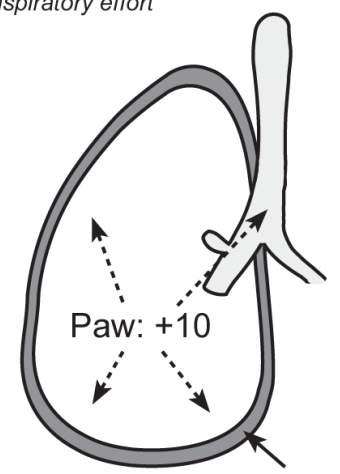

Ppl: -15

Ptp $=+10-(-15)=+25 \mathrm{cmH}_{2} \mathrm{O}$
B. Lean, intubated, normal lungs: end-inspiration during positive pressure ventilation while passive

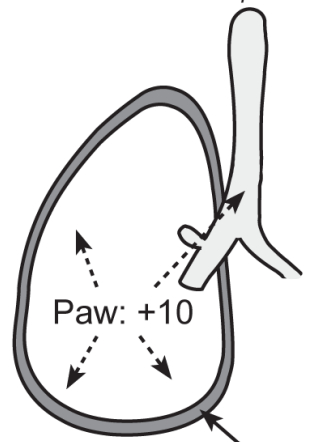

Ppl: 0

Ptp $=+10-(0)=+10 \mathrm{cmH}_{2} \mathrm{O}$

D. Obese, intubated, normal lungs: end-inspiration during positive pressure ventilation while passive

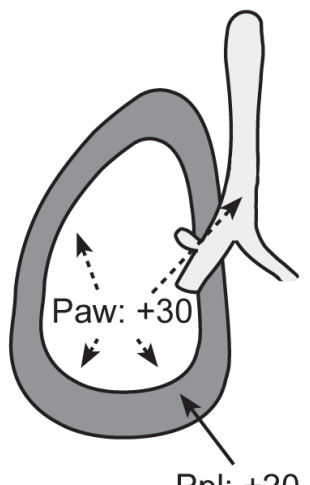

Ptp $=+30-(+20)=+10 \mathrm{cmH}_{2} \mathrm{O}$

Figure 3. Transpulmonary pressure (Pairway - Ppleural) is the pertinent distending pressure of the lung. Measurements to ascertain lung distension at end-inspiration and end-expiration are taken during breath holds, at which time air flow is zero and airway pressure equilibrates throughout communicating airways. (A) Lean, non-intubated patient with normal spontaneous tidal breathing at end inspiration. Transpulmonary pressure of $5-10 \mathrm{cmH}_{2} \mathrm{O}$ is typical at end inspiration in lean healthy individuals. (B) Lean, intubated patient during positive pressure ventilation at end inspiration while passive. (C) Lean, intubated patient with forceful inspiratory effort has produced very high transpulmonary pressure that would be unsafe in patients at risk of ventilation-induced lung injury (VILI) despite the relatively low airway pressure. The observed transpulmonary pressure of $25 \mathrm{cmH}_{2} \mathrm{O}$ is typical at total lung capacity in lean healthy individuals. (D) Obese, intubated patient, with chest wall contributing high pleural pressure that results in lower transpulmonary pressure and lower lung volume at end inspiration despite higher airway pressure. Even though plateau airway pressure is relatively high, the risk of VILI is lower because lung volume and transpulmonary pressure are lower. Paw, airway pressure; Ppl, pleural pressure; Ptp, transpulmonary pressure. This figure was adapted from Beitler J, Malhotra A, and Thompson B, Ventilator-induced lung injury. Clin Chest Med doi:10.1016/j.ccm.2016.07.004 with permission $^{74}$. 
20-25 $\mathrm{cmH}_{2} \mathrm{O}$ is the typical range observed at total lung capacity in healthy individuals ${ }^{75}$, and this value therefore can be thought of as the maximal stress the lungs experience in normal life. A transpulmonary pressure of $5-10 \mathrm{cmH}_{2} \mathrm{O}$ is characteristic of end-inspiration during normal tidal ventilation, and a value of around $0 \mathrm{cmH}_{2} \mathrm{O}$ (depending on body position) is typical in lean healthy individuals at relaxed end-exhalation ${ }^{3,73,76-79}$. While transpulmonary pressure is most often used for setting $\mathrm{PEEP}^{37,80}$, its potential role to guide tidal volume targets is an area of active investigation.

Airway driving pressure may be a more universally available surrogate to individualize tidal volume ${ }^{81}$. Airway driving pressure, calculated as plateau pressure minus PEEP, is mathematically equivalent to the tidal volume scaled to respiratory system compliance. In an individual patient meta-analysis of multiple clinical trials, higher driving pressure was associated with increased mortality in patients with $\mathrm{ARDS}^{65}$. Although there is no clear threshold effect, one might reasonably interpret values of $10 \mathrm{cmH}_{2} \mathrm{O}$ or less as within the range of normal for healthy individuals based on data using esophageal manometry ${ }^{77-79}$, and thus a reasonable target range in ARDS, although heterogeneous stress distribution from alveolar interdependence may still predispose to VILI in injured lungs.

\section{Monitoring regional mechanics}

Recent technological advances may permit monitoring regional hyperinflation and atelectrauma at bedside. Lung electrical impedance tomography (EIT) is a potentially revolutionary tool that facilitates evaluating regional lung distension in real time. Current commercial lung EIT interfaces consist of a belt, containing multiple electrodes, that is placed around the mid-chest. Images qualitatively resemble a single cross-sectional slice from a computed tomography scan (although containing different information) and are acquired non-invasively and without radiation. Technical aspects of EIT are reviewed elsewhere ${ }^{82}$. EIT was used in the discovery that spontaneous effort can cause transient hyperinflation from Pendelluft ${ }^{83}$, and has been used to quantify tidal opening collapse, end-tidal hyperinflation, and regional mechanical heterogeneity ${ }^{84-86}$. Current commercial devices are not without limitations ${ }^{87}$. The extent to which a single cross-sectional plane from EIT can be used to make inferences about the whole lung is debatable, and EIT's spatial resolution within that cross-sectional slice is markedly less than that of computed tomography (CT). Strategies for EIT-guided ventilation must be developed and tested in clinical trials before widespread adoption. Still, as technology and the device interface continue to improve, there is considerable potential for EIT monitoring to provide new information at bedside regarding regional ventilation that may help guide lung-protective ventilation in the future.

\section{Preventing VILI}

Tidal volume targets

Maintaining a tidal volume of $4-8 \mathrm{~mL} / \mathrm{kg} \mathrm{PBW}$ and a plateau pressure of $\leq 30 \quad \mathrm{cmH}_{2} \mathrm{O}$ are reasonable initial ventilation targets, following the ARDS Network strategy ${ }^{2}$. However, recent mechanistic clinical trials suggest that lowering tidal volumes to $3-4 \mathrm{~mL} / \mathrm{kg}$ PBW, using extracorporeal gas exchange as needed, further attenuates pulmonary and systemic inflammation (biotrauma) in patients with severe $\operatorname{ARDS}^{10,11}$.

Lending further weight to this possibility is the recently published, controversial EOLIA trial ${ }^{88}$. EOLIA compared a conventional tidal volume strategy of $6 \mathrm{~mL} / \mathrm{kg}$ PBW tidal volume with a plateau pressure of $28-30 \mathrm{cmH}_{2} \mathrm{O}$ versus an "ultra-low" tidal volume strategy targeting a plateau pressure of $\leq 24 \mathrm{cmH}_{2} \mathrm{O}$ facilitated via extracorporeal membrane oxygenation (ECMO) in patients with very severe ARDS. Sixty-day mortality was $46 \%$ with the conventional strategy versus $35 \%$ with the ECMO-facilitated ultra-low tidal volume strategy, a clinically important difference that did not achieve statistical significance. Reframing EOLIA not as an ECMO trial per se but as a VILI prevention trial means that the interpretation that ultra-low tidal volumes near $3 \mathrm{~mL} / \mathrm{kg}$ PBW may confer additional benefit in very severe ARDS has sound biological plausibility, though available data are not definitive.

\section{Mitigating heterogeneous stress/strain distribution via prone positioning}

At first glance, it might seem difficult to target heterogeneous lung insufflation with clinical management. Targeting lower tidal volume decreases the magnitude of deformation even with lung heterogeneity but does not alter the underlying heterogeneity.

Prone positioning is one strategy to facilitate more homogeneous lung aeration and more uniform strain distribution. Proning directs gravitational forces to offset forces from shape-matching of the lungs to the thoracic cavity ${ }^{89}$. Indeed, this decrease in heterogeneity is thought to be a principle mechanism by which proning affords benefit ${ }^{90}$. Early prone positioning was shown in a multicenter trial of moderate-severe ARDS to improve survival $^{9}$, and it remains underutilized in clinical practice ${ }^{91}$. Discordant findings across trials of prone positioning may explain this practice inertia, but several factors explain why the latest trial may have differed from others: low tidal volumes were mandated per protocol unlike several older trials, patients were prone for at least 16 hours/day, proning was done early rather than as rescue, and proning was continued daily until patients demonstrated durable improvement in lung function ${ }^{92}$.

\section{Atelectrauma and PEEP titration}

There remains no convincing data to recommend a particular PEEP titration strategy in ARDS. Trials comparing an empiric high-PEEP strategy to a lower PEEP strategy have not demonstrated benefit with either strategy but also have not shown greater risk of barotrauma with higher PEEP ${ }^{34,35}$. In contrast, the recent Alveolar Recruitment Trial ${ }^{36}$ found increased barotrauma and mortality with PEEP titrated to reduce driving pressure compared to an empiric low-PEEP strategy, but concomitant use of an unusually aggressive recruitment maneuver in the intervention arm (stepwise recruitment up to PEEP $45 \mathrm{cmH}_{2} \mathrm{O}$ with driving pressure $15 \mathrm{cmH}_{2} \mathrm{O}$ over several minutes) likely contributed to harm associated with the intervention. 
Esophageal pressure-guided PEEP to maintain a non-negative transpulmonary pressure was compared to a low-PEEP strategy in a small single-center trial and found improved survival after adjusting for overall illness severity ${ }^{80}$. However, a larger multicenter trial comparing esophageal pressure-guided PEEP to empiric high PEEP found no significant difference in mortality ${ }^{37}$. Differences in the comparator arm between trials may explain these seemingly discrepant outcomes ${ }^{91}$.

More broadly, uptitrating PEEP likely has tradeoffs for VILI. Any benefit of preventing atelectrauma may be offset by increasing end-tidal hyperinflation whenever end-inspiratory pressures also increase. Simultaneous lowering of tidal volume as PEEP is increased would negate exacerbating overdistension, but whether such an approach affords clinical benefit has not been tested in a clinical trial to date.

\section{Spontaneous breathing}

The potential importance of PSILI to clinical management is yet to be defined. For mechanically ventilated patients with ARDS at greatest risk of VILI, one recent multicenter trial suggested neuromuscular blockade for 48 hours improved survival in patients with moderate-severe ARDS compared to a deep sedation strategy without neuromuscular blockade ${ }^{93}$. However, a second recent trial demonstrated no discernable benefit with neuromuscular blockade when compared to a management strategy prioritizing light sedation ${ }^{94}$. Several differences between the trials might explain their discordant findings ${ }^{96}$, but some experts still believe there may be a role for suppressing respiratory drive in severe ARDS when forceful spontaneous respiratory efforts produce higher tidal volumes than intended ${ }^{3,97}$.

Sedation alone may not consistently eliminate patient effort ${ }^{97,98}$. Common ventilator modes, including pressure support and any form of assist-control, also are ineffective at limiting tidal volume. Even in volume-targeted modes, breath stacking dyssynchrony may yield higher volume changes than intended, generated from consecutive inspiratory cycles with incomplete exhalation between them ${ }^{97,98,100}$.

Spontaneous respiratory effort also may play a role in regional overdistension. Spontaneous inspiratory effort during invasive ventilation can produce transient regional hyperinflation via pendelluft (transient air movement between alveoli within the lung), which theoretically also could be injurious ${ }^{81}$. The extent to which this observation is clinically relevant is unknown.

Patient-ventilator interactions are often intermittent and effort variable over time. The dose response of such interactions with VILI remains unclear. Dyssynchronies such as double or reverse triggering that produce breath stacking may be injurious via repeated exposure to high tidal volumes, but intermittent exposure has unclear significance and could be beneficial to maintaining lung recruitment. As a result, the optimal management strategy also remains unclear. Whether to pursue deep sedation and/or introduce neuromuscular blockade to suppress respiratory drive and facilitate passive ventilation requires weighing several factors ${ }^{43}$ : biological predisposition to VILI ${ }^{61,101,102}$, heterogeneity of regional lung mechanics ${ }^{41,42,103,104}$, delays in early patient mobilization with risk of ICU-acquired weakness $^{105-107}$, and risk of diaphragm disuse atrophy that might prolong ventilator dependence and hospital stay ${ }^{108-110}$, among other factors. In high-risk patients with severe ARDS, frequent breath stacking in particular is likely to be injurious and warrant suppression. In cases of mild ARDS, less frequent breath stacking, or other patient-ventilator interactions, the risk/benefit of suppressing patient effort is less clear.

For the non-intubated patient with concern for PSILI, how to optimize management remains to be defined. High-flow nasal cannula exerts several physiologic effects that may be lung protective in the at-risk patient and warrant further study ${ }^{111,112}$. How best to optimize noninvasive positive pressure ventilation remains unclear and may depend on the device interface used $^{113,114}$. In patients with ARDS or purely hypoxemic respiratory failure, high-flow nasal cannula appears to be the preferred noninvasive support strategy based on available evidence $^{115}$. Given the many co-interventions that come with invasive ventilation, prophylactic intubation seems unlikely to be beneficial, although delayed intubation in patients failing noninvasive support also may be deleterious ${ }^{116}$.

\section{Conclusions}

Over two decades after the first landmark trial from Amato and colleagues ${ }^{1}$, protection against VILI remains the central treatment for ARDS. The extent to which patients without ARDS or who are not intubated experience ventilation-induced lung injury is unclear. Current best practice for lung protection involves weighing bedside assessment of individual patient-specific risk of VILI against tradeoffs of possible interventions. This risk/benefit analysis should be guided by expert clinical judgement with interpretation of respiratory mechanicsmeasures that do not exhibit a threshold effect. In the years ahead, technological and molecular diagnostic advances may help guide that risk assessment in a more precise manner. While there remains no consensus on the optimal strategy to personalize ventilatory support for VILI protection, there is universal agreement that protection against VILI improves morbidity and mortality in at-risk patients.

\section{Abbreviations}

ARDS, acute respiratory distress syndrome; ECMO, extracorporeal membrane oxygenation; EIT, electrical impedance tomography; PEEP, positive end-expiratory pressure; PBW, predicted body weight; VILI, ventilation-induced lung injury. 
1. Amato MB, Barbas CS, Medeiros DM, et al:: Effect of a protective-ventilation strategy on mortality in the acute respiratory distress syndrome. N Engl J Med. 1998; 338(6): 347-54

PubMed Abstract | Publisher Full Text

2. F Acute Respiratory Distress Syndrome Network, Brower RG, Matthay MA, et al. Ventilation with lower tidal volumes as compared with traditional tidal volumes for acute lung injury and the acute respiratory distress syndrome. $N$ Engl $J$ Med. 2000; 342(18): 1301-8.

PubMed Abstract | Publisher Full Text | F1000 Recommendation

3. Slutsky AS, Ranieri VM: Ventilator-induced lung injury. N Engl J Med. 2013; 369(22): 2126-36.

PubMed Abstract | Publisher Full Text

4. Matthay MA, Zemans RL, Zimmerman GA, et al:: Acute respiratory distress syndrome. Nat Rev Dis Primers. 2019; 5(1): 18 PubMed Abstract | Publisher Full Text | Free Full Text

5. $\quad$ F Lanspa MJ, Gong MN, Schoenfeld DA, et al:: Prospective Assessment of the Feasibility of a Trial of Low Tidal Volume Ventilation for Patients with Acute Respiratory Failure. Ann Am Thorac Soc. 2019; 16(3): 356-362. PubMed Abstract | Publisher Full Text | Free Full Text | F1000 Recommendation

6. Serpa Neto A, Cardoso SO, Manetta JA, et al:: Association between use of lungprotective ventilation with lower tidal volumes and clinical outcomes among patients without acute respiratory distress syndrome: A meta-analysis. JAMA. 2012; 308(16): 1651-9.

PubMed Abstract | Publisher Full Text

7. $\quad F$ Sjoding MW, Gong MN, Haas CF, et al:: Evaluating Delivery of Low Tidal Volume Ventilation in Six ICUs Using Electronic Health Record Data. Crit Care Med. 2019; 47(1): 56-61.

PubMed Abstract | Publisher Full Text | Free Full Text | F1000 Recommendation

8. Elmer J, Hou P, Wilcox SR, et al.: Acute Respiratory Distress Syndrome After Spontaneous Intracerebral Hemorrhage*. Crit Care Med. 2013; 41(8): 1992-2001.

PubMed Abstract | Publisher Full Text | Free Full Text

9. $\quad \mathrm{F}$ Guérin $\mathrm{C}$, Reignier J, Richard JC, et al.: Prone positioning in severe acute respiratory distress syndrome. N Engl J Med. 2013; 368(23): 2159-68. PubMed Abstract | Publisher Full Text | F1000 Recommendation

10. F Bein T, Weber-Carstens S, Goldmann A, et al:: Lower tidal volume strategy $(\approx 3 \mathrm{ml} / \mathrm{kg})$ combined with extracorporeal $\mathrm{CO}_{2}$ removal versus 'conventional' protective ventilation $(6 \mathrm{ml} / \mathrm{kg})$ in severe ARDS: The prospective randomized Xtravent-study. Intensive Care Med. 2013; 39(5): 847-56.

PubMed Abstract | Publisher Full Text | Free Full Text | F1000 Recommendation

11. F Terragni PP, Del Sorbo L, Mascia L, et al:: Tidal volume lower than $6 \mathrm{ml} / \mathrm{kg}$ enhances lung protection: role of extracorporeal carbon dioxide removal. Anesthesiology. 2009; 111(4): 826-35.

PubMed Abstract | Publisher Full Text | F1000 Recommendation

12. Slutsky AS: Lung Injury Caused by Mechanical Ventilation. Chest. 1999; 116 (1 Suppl): 9S-15S.

PubMed Abstract | Publisher Full Text

13. Three Hunterian Lectures ON THE MECHANISM UNDERLYING THE VARIOUS METHODS OF ARTIFICIAL RESPIRATION PRACTISED SINCE THE FOUNDATION OF THE ROYAL HUMANE SOCIETY IN 1774. The Lancet. 1909; 173(4464): 825-8.

Publisher Full Text

14. Slutsky AS: History of Mechanical Ventilation. From Vesalius to Ventilatorinduced Lung Injury. Am J Respir Crit Care Med. 2015; 191(10): 1106-15. PubMed Abstract | Publisher Full Text

15. Webb HH, Tierney DF: Experimental pulmonary edema due to intermittent positive pressure ventilation with high inflation pressures. Protection by positive end-expiratory pressure. Am Rev Respir Dis. 1974; 110(5): 556-65. PubMed Abstract

16. F ARDS Definition Task Force, Ranieri VM, Rubenfeld GD, et al.: Acute respiratory distress syndrome: The Berlin Definition. JAMA. 2012; 307(23): 2526-33.

PubMed Abstract | Publisher Full Text | F1000 Recommendation

17. Ferguson ND, Fan E, Camporota L, et al:: The Berlin definition of ARDS: An expanded rationale, justification, and supplementary material. Intensive Care Med. 2012; 38(10): 1573-82.

PubMed Abstract | Publisher Full Text

18. Dreyfuss $D$, Soler $P$, Basset $G$, et al:: High inflation pressure pulmonary edema Respective effects of high airway pressure, high tidal volume, and positive end-expiratory pressure. Am Rev Respir Dis. 1988; 137(5): 1159-64. PubMed Abstract | Publisher Full Text

19. $\mathrm{F}$ Chiumello $\mathrm{D}$, Carlesso $\mathrm{E}$, Cadringher $\mathrm{P}$, et al:: Lung stress and strain during mechanical ventilation for acute respiratory distress syndrome. Am J Respir Crit Care Med. 2008; 178(4): 346-55.

PubMed Abstract | Publisher Full Text | F1000 Recommendation

20. Brower RG, Hubmayr RD, Slutsky AS: Lung stress and strain in acute respiratory distress syndrome: Good ideas for clinical management? Am J
Respir Crit Care Med. 2008; 178(4): 323-4.

PubMed Abstract | Publisher Full Text

21. Talmor D, Sarge T, O Donnell CR, et al.: Esophageal and transpulmonary pressures in acute respiratory failure. Crit Care Med. 2006; 34(5): 1389-94. PubMed Abstract | Publisher Full Text | Free Full Text

22. Loring $\mathrm{SH}, \mathrm{O}$ 'Donnell $\mathrm{CR}$, Behazin $\mathrm{N}$, et al:: Esophageal pressures in acute lung injury: Do they represent artifact or useful information about transpulmonary pressure, chest wall mechanics, and lung stress? J Appl Physiol (1985). 2010; 108(3): 515-22

PubMed Abstract | Publisher Full Text | Free Full Text

23. Mead J, Takishima T, Leith D: Stress distribution in lungs: A model of pulmonary elasticity. J Appl Physiol. 1970; 28(5): 596-608.

PubMed Abstract | Publisher Full Text

24. Loring SH, Topulos GP, Hubmayr RD: Transpulmonary Pressure: The Importance of Precise Definitions and Limiting Assumptions. Am J Respir Crit Care Med. 2016; 194(12): 1452-7.

PubMed Abstract | Publisher Full Text

25. Muscedere JG, Mullen JB, Gan K, et al.: Tidal ventilation at low airway pressures can augment lung injury. Am J Respir Crit Care Med. 1994; 149(5): 1327-34. PubMed Abstract | Publisher Full Text

26. Taskar V, John J, Evander E, et al:: Surfactant dysfunction makes lungs vulnerable to repetitive collapse and reexpansion. Am J Respir Crit Care Med. 1997; 155(1): 313-20.

PubMed Abstract | Publisher Full Text

27. Albert RK: The role of ventilation-induced surfactant dysfunction and atelectasis in causing acute respiratory distress syndrome. Am J Respir Crit Care Med. 2012; 185(7): 702-8.

PubMed Abstract | Publisher Full Text

28. Ghadiali SN, Gaver DP: Biomechanics of liquid-epithelium interactions in pulmonary airways. Respir Physiol Neurobiol. 2008; 163(1-3): 232-43. PubMed Abstract | Publisher Full Text | Free Full Text

29. Bilek AM, Dee KC, Gaver DP: Mechanisms of surface-tension-induced epithelial cell damage in a model of pulmonary airway reopening. J Appl Physiol (1985). 2003; 94(2): 770-83. PubMed Abstract | Publisher Full Text

30. $\mathrm{F}$ Hamlington $\mathrm{KL}$, Smith $\mathrm{BJ}$, Dunn $\mathrm{CM}$, et al.: Linking lung function to structural damage of alveolar epithelium in ventilator-induced lung injury. Respir Physiol Neurobiol. 2018; 255: 22-9.

PubMed Abstract | Publisher Full Text | Free Full Text | F1000 Recommendation

31. Lutz D, Gazdhar A, Lopez-Rodriguez E, et al.: Alveolar derecruitment and collapse induration as crucial mechanisms in lung injury and fibrosis. $\mathrm{Am} \mathrm{J}$ Respir Cell Mol Biol. 2015; 52(2): 232-43.

PubMed Abstract | Publisher Full Text

32. Steinberg JM, Schiller HJ, Halter JM, et al.: Alveolar instability causes early ventilator-induced lung injury independent of neutrophils. Am J Respir Crit Care Med. 2004; 169(1): 57-63.

PubMed Abstract | Publisher Full Text

33. $\mathrm{F}$ Bellani G, Laffey JG, Pham T, et al.: Noninvasive Ventilation of Patients with Acute Respiratory Distress Syndrome. Insights from the LUNG SAFE Study. Am J Respir Crit Care Med. 2017; 195(1): 67-77.

PubMed Abstract | Publisher Full Text | F1000 Recommendation

34. Brower RG, Lanken PN, Macintyre N, et al:: Higher versus lower positive endexpiratory pressures in patients with the acute respiratory distress syndrome. N Engl J Med. 2004; 351(4): 327-36.

PubMed Abstract | Publisher Full Text

35. F Meade MO, Cook DJ, Guyatt GH, et al.: Ventilation strategy using low tidal volumes, recruitment maneuvers, and high positive end-expiratory pressure for acute lung injury and acute respiratory distress syndrome: a randomized controlled trial. JAMA. 2008; 299(6): 637-45.

PubMed Abstract | Publisher Full Text | F1000 Recommendation

36. F Writing Group for the Alveolar Recruitment for Acute Respiratory Distress Syndrome Trial (ART) Investigators, Cavalcanti AB, Suzumura ÉA, et al.: Effect of Lung Recruitment and Titrated Positive End-Expiratory Pressure (PEEP) vs Low PEEP on Mortality in Patients With Acute Respiratory Distress Syndrome: A Randomized Clinical Trial. JAMA. 2017; 318(14): 1335-45.

PubMed Abstract | Publisher Full Text | Free Full Text | F1000 Recommendation

37. F Beitler JR, Sarge T, Banner-Goodspeed VM, et al:: Effect of Titrating Positive End-Expiratory Pressure (PEEP) With an Esophageal Pressure-Guided Strategy vs an Empirical High PEEP-Fio2 Strategy on Death and Days Free From Mechanical Ventilation Among Patients With Acute Respiratory Distress Syndrome: A Randomized Clinical Trial. JAMA. 2019; 321(9): 846-57. PubMed Abstract | Publisher Full Text | Free Full Text | F1000 Recommendation

38. F Knudsen L, Lopez-Rodriguez E, Berndt L, et al:: Alveolar Micromechanics in Bleomycin-induced Lung Injury. Am J Respir Cell Mol Biol. 2018; 59(6): 757-69. PubMed Abstract | Publisher Full Text | Free Full Text | F1000 Recommendation

39. F Albert RK, Smith B, Perlman CE, et al:: Is Progression of Pulmonary Fibrosis due to Ventilation-induced Lung Injury? Am J Respir Crit Care Med. 2019; 
200(2): 140-51.

PubMed Abstract | Publisher Full Text | Free Full Text | F1000 Recommendation

40. F Perlman CE, Lederer DJ, Bhattacharya J: Micromechanics of alveolar edema. Am J Respir Cell Mol Biol. 2011; 44(1): 34-9.

PubMed Abstract | Publisher Full Text | Free Full Text | F1000 Recommendation

41. Cressoni $M$, Chiumello D, Chiurazzi $C$, et al:: Lung inhomogeneities, inflation and $\left[{ }^{18} \mathrm{~F}\right] 2$-fluoro-2-deoxy-D-glucose uptake rate in acute respiratory distress syndrome. Eur Respir J. 2015; 47(1): 233-42.

PubMed Abstract | Publisher Full Text

42. Cressoni $\mathrm{M}$, Cadringher $\mathrm{P}$, Chiurazzi $\mathrm{C}$, et al:: Lung inhomogeneity in patients with acute respiratory distress syndrome. Am J Respir Crit Care Med. 2014; 189(2): 149-58.

PubMed Abstract | Publisher Full Text

43. Beitler JR: Bedside respiratory physiology to detect risk of lung injury in acute respiratory distress syndrome. Curr Opin Crit Care. 2019; 25(1): 3-11. PubMed Abstract | Publisher Full Text | Free Full Text

44. Wellman TJ, Winkler T, Costa EL, et al.: Effect of local tidal lung strain on inflammation in normal and lipopolysaccharide-exposed sheep*. Crit Care Med. 2014; 42(7): e491-e500.

PubMed Abstract | Publisher Full Text | Free Full Text

45. Mascheroni $\mathrm{D}$, Kolobow $\mathrm{T}$, Fumagalli $\mathrm{R}$, et al:: Acute respiratory failure following pharmacologically induced hyperventilation: an experimental animal study. Intensive Care Med. 1988; 15(1): 8-14. PubMed Abstract | Publisher Full Text

46. F Curley GF, Laffey JG, Zhang $\mathrm{H}$, et al:: Biotrauma and Ventilator-Induced Lung Injury: Clinical Implications. Chest. 2016; 150(5): 1109-17. PubMed Abstract | Publisher Full Text | F1000 Recommendation

47. F Brochard L, Slutsky A, Pesenti A: Mechanical Ventilation to Minimize Progression of Lung Injury in Acute Respiratory Failure. Am J Respir Crit Care Med. 2017; 195(4): 438-42.

PubMed Abstract | Publisher Full Text | F1000 Recommendation

48. F Brochard L: Ventilation-induced lung injury exists in spontaneously breathing patients with acute respiratory failure: Yes. Intensive Care Med. 2017; 43(2): 250-2.

PubMed Abstract | Publisher Full Text | F1000 Recommendation

49. Yoshida T, Uchiyama A, Matsuura N, et al.: The comparison of spontaneous breathing and muscle paralysis in two different severities of experimental lung injury. Crit Care Med. 2013; 41(2): 536-45.

PubMed Abstract | Publisher Full Text

50. Yoshida T, Uchiyama A, Matsuura N, et al.: Spontaneous breathing during lung-protective ventilation in an experimental acute lung injury model: high transpulmonary pressure associated with strong spontaneous breathing effort may worsen lung injury. Crit Care Med. 2012; 40(5): 1578-85.

PubMed Abstract | Publisher Full Text

51. Tremblay L, Valenza F, Ribeiro SP, et al.: Injurious ventilatory strategies increase cytokines and $\mathrm{c}$-fos $\mathrm{m}$-RNA expression in an isolated rat lung model. J Clin Invest. 1997; 99(5): 944-52.

PubMed Abstract | Publisher Full Text | Free Full Text

52. Imai $\mathrm{Y}$, Parodo J, Kajikawa $\mathrm{O}$, et al:: Injurious mechanical ventilation and end-organ epithelial cell apoptosis and organ dysfunction in an experimenta model of acute respiratory distress syndrome. JAMA. 2003; 289(16): 2104-12. PubMed Abstract | Publisher Full Text

53. Ranieri VM, Suter PM, Tortorella C, et al.: Effect of mechanical ventilation on inflammatory mediators in patients with acute respiratory distress syndrome: a randomized controlled trial. JAMA. 1999; 282(1): 54-61.

PubMed Abstract | Publisher Full Text

54. Chiumello D, Pristine G, Slutsky AS: Mechanical ventilation affects local and systemic cytokines in an animal model of acute respiratory distress syndrome. Am J Respir Crit Care Med. 1999; 160(1): 109-16. PubMed Abstract | Publisher Full Text

55. Tolle LB, Standiford TJ: Danger-associated molecular patterns (DAMPs) in acute lung injury. J Pathol. 2013; 229(2): 145-56. PubMed Abstract | Publisher Full Text

56. Tracey KJ: Physiology and immunology of the cholinergic antiinflammatory pathway. J Clin Invest. 2007; 117(2): 289-96.

PubMed Abstract | Publisher Full Text | Free Full Text

57. Tracey KJ: The inflammatory reflex. Nature. 2002; 420(6917): 853-9. PubMed Abstract | Publisher Full Text

58. Ranieri VM, Giunta F, Suter PM, et al.: Mechanical ventilation as a mediator of multisystem organ failure in acute respiratory distress syndrome. JAMA. 2000; 284(1): 43-4.

PubMed Abstract

59. Parsons PE, Eisner MD, Thompson BT, et al.: Lower tidal volume ventilation and plasma cytokine markers of inflammation in patients with acute lung injury. Crit Care Med. 2005; 33(1): 1-6.

PubMed Abstract | Publisher Full Text

60. F Jabaudon M, Blondonnet R, Pereira B, et al:: Plasma sRAGE is independently associated with increased mortality in ARDS: a meta-analysis of individual patient data. Intensive Care Med. 2018; 44(9): 1388-99. PubMed Abstract | Publisher Full Text | Free Full Text | F1000 Recommendation

61. Calfee CS, Ware LB, Eisner MD, et al:: Plasma receptor for advanced glycation end products and clinical outcomes in acute lung injury. Thorax. 2008; 63(12):
$1083-9$

PubMed Abstract | Publisher Full Text | Free Full Text

62. Ware LB, Koyama T, Zhao Z, et al:: Biomarkers of lung epithelial injury and inflammation distinguish severe sepsis patients with acute respiratory distress syndrome. Crit Care. 2013; 17(5): R253.

PubMed Abstract | Publisher Full Text | Free Full Text

63. F Hager DN, Krishnan JA, Hayden DL, et al:: Tidal volume reduction in patients with acute lung injury when plateau pressures are not high. $A m \mathrm{~J}$ Respir Crit Care Med. 2005; 172(10): 1241-5.

PubMed Abstract | Publisher Full Text | Free Full Text | F1000 Recommendation

64. Beitler JR, Majumdar R, Hubmayr RD, et al:: Volume Delivered During Recruitment Maneuver Predicts Lung Stress in Acute Respiratory Distress Syndrome. Crit Care Med. 2016; 44(1): 91-9.

PubMed Abstract | Publisher Full Text | Free Full Text

65. F Amato MB, Meade MO, Slutsky AS, et al.: Driving pressure and survival in the acute respiratory distress syndrome. N Engl J Med. 2015; 372(8): 747-55. PubMed Abstract | Publisher Full Text | F1000 Recommendation

66. Gajic O, Dabbagh O, Park PK, et al.: Early identification of patients at risk of acute lung injury: evaluation of lung injury prediction score in a multicenter cohort study. Am J Respir Crit Care Med. 2011; 183(4): 462-70.

PubMed Abstract | Publisher Full Text | Free Full Text

67. Michelet $\mathrm{P}, \mathrm{D}$ 'Journo $\mathrm{XB}$, Roch $\mathrm{A}$, et al:: Protective ventilation influences systemic inflammation after esophagectomy: a randomized controlled study. Anesthesiology. 2006; 105(5): 911-9.

PubMed Abstract | Publisher Full Tex

68. Gattinoni L, Pesenti A: The concept of "baby lung". Intensive Care Med. 2005; 31(16): $776-84$

PubMed Abstract | Publisher Full Tex

69. $\mathrm{F}$ Gattinoni $\mathrm{L}$, Caironi $\mathrm{P}$, Cressoni $\mathrm{M}$, et al.: Lung recruitment in patients with the acute respiratory distress syndrome. N Engl J Med. 2006; 354(17): 1775-86. PubMed Abstract | Publisher Full Text | F1000 Recommendation

70. Loring SH, Behazin N, Novero A, et al:: Respiratory mechanical effects of surgical pneumoperitoneum in humans. J Appl Physiol (1985). 2014; 117(9): $1074-9$.

PubMed Abstract | Publisher Full Text | Free Full Text

71. F Fumagalli J, Berra L, Zhang C, et al:: Transpulmonary Pressure Describes Lung Morphology During Decremental Positive End-Expiratory Pressure Trials in Obesity. Crit Care Med. 2017; 45(8): 1374-81.

PubMed Abstract | Publisher Full Text | F1000 Recommendation

72. F Akoumianaki E, Maggiore SM, Valenza F, et al:: The application of esophageal pressure measurement in patients with respiratory failure. $A m \mathrm{~J}$ Respir Crit Care Med. 2014; 189(5): 520-31.

PubMed Abstract | Publisher Full Text | F1000 Recommendation

73. Mauri T, Yoshida T, Bellani G, et al.: Esophageal and transpulmonary pressure in the clinical setting: meaning, usefulness and perspectives. Intensive Care Med 2016; 42(9): 1360-73

PubMed Abstract | Publisher Full Text

74. Beitler JR, Malhotra A, Thompson BT: Ventilator-induced Lung Injury. Clin Chest Med. 2016; 37(4): 633-646.

PubMed Abstract | Publisher Full Text | Free Full Text

75. Loring SH, O'Donnell CR, Butler JP, et al:: Transpulmonary pressures and lung mechanics with glossopharyngeal insufflation and exsufflation beyond norma lung volumes in competitive breath-hold divers. J Appl Physiol (1985). 2007; 102(3): 841-6.

PubMed Abstract | Publisher Full Text

76. Washko GR, O'Donnell CR, Loring SH: Volume-related and volume-independent effects of posture on esophageal and transpulmonary pressures in healthy subjects. J Appl Physiol (1985). 2006; 100(3): 753-8.

PubMed Abstract | Publisher Full Text

77. Mead J, Gaensler EA: Esophageal and pleural pressures in man, upright and supine. J Appl Physiol. 1959; 14(1): 81-3.

PubMed Abstract | Publisher Full Text

78. Cherniack RM, Farhi LE, Armstrong BW, et al:: A comparison of esophageal and intrapleural pressure in man. J Appl Physiol. 1955; 8(2): 203-11. PubMed Abstract | Publisher Full Text

79. Behazin N, Jones SB, Cohen RI, et al:: Respiratory restriction and elevated pleural and esophageal pressures in morbid obesity. J Appl Physiol (1985). 2010; 108(1): 212-8.

PubMed Abstract | Publisher Full Text | Free Full Text

80. F Talmor D, Sarge T, Malhotra A: Mechanical ventilation guided by esophageal pressure in acute lung injury. N Engl J Med. 2008; 359(20): 2095-104.

PubMed Abstract | Publisher Full Text | Free Full Text | F1000 Recommendation

81. F Henderson WR, Chen L, Amato MBP, et al:: Fifty Years of Research in ARDS. Respiratory Mechanics in Acute Respiratory Distress Syndrome. Am J Respir Crit Care Med. 2017; 196(7): 822-33.

PubMed Abstract | Publisher Full Text | F1000 Recommendation

82. Leonhardt S, Lachmann B: Electrical impedance tomography: the holy grail of ventilation and perfusion monitoring? Intensive Care Med. 2012; 38(12): 1917-29. PubMed Abstract | Publisher Full Text

83. Yoshida T, Torsani V, Gomes S, et al.: Spontaneous effort causes occult 
pendelluft during mechanical ventilation. Am J Respir Crit Care Med. 2013; 188(12): $1420-7$

PubMed Abstract | Publisher Full Text

84. Costa ELV, Borges JB, Melo A, et al.: Bedside estimation of recruitable alveola collapse and hyperdistension by electrical impedance tomography. Intensive Care Med. 2009; 35(6): 1132-7.

PubMed Abstract | Publisher Full Text

85. Victorino JA, Borges JB, Okamoto VN, et al.: Imbalances in regional lung ventilation: a validation study on electrical impedance tomography. $A m \mathrm{~J}$ Respir Crit Care Med. 2004; 169(7): 791-800.

PubMed Abstract | Publisher Full Text

86. Zhao Z, Möller K, Steinmann D, et al: Evaluation of an electrical impedance tomography-based global inhomogeneity index for pulmonary ventilation distribution. Intensive Care Med. 2009; 35(11): 1900-6. PubMed Abstract | Publisher Full Text

87. Lundin S, Stenqvist O: Electrical impedance tomography: potentials and pitfalls. Curr Opin Crit Care. 2012; 18(1): 35-41. PubMed Abstract | Publisher Full Text

88. F Combes A, Hajage D, Capellier G, et al:: Extracorporeal Membrane Oxygenation for Severe Acute Respiratory Distress Syndrome. N Engl J Med. 2018; 378(21): 1965-75.

PubMed Abstract | Publisher Full Text | F1000 Recommendation

89. Pelosi P, D'Andrea L, Vitale G: Vertical gradient of regional lung inflation in adult respiratory distress syndrome. Am J Respir Crit Care Med. 1994; 149(1): $8-13$

PubMed Abstract | Publisher Full Text

90. Gattinoni L, Taccone P, Carlesso E, et al: Prone position in acute respiratory distress syndrome. Rationale, indications, and limits. Am J Respir Crit Care Med. 2013; 188(11): 1286-93. PubMed Abstract | Publisher Full Text

91. F Bellani G, Laffey JG, Pham T, et al.: Epidemiology, Patterns of Care, and Mortality for Patients With Acute Respiratory Distress Syndrome in Intensive Care Units in 50 Countries. JAMA. 2016; 315(8): 788-800 PubMed Abstract | Publisher Full Text | F1000 Recommendation

92. Beitler JR, Shaefi S, Montesi SB, et al:: Prone positioning reduces mortality from acute respiratory distress syndrome in the low tidal volume era: A metaanalysis. Intensive Care Med. 2014; 40(3): 332-41. PubMed Abstract | Publisher Full Text | Free Full Text

93. Beitler JR, Talmor D: Strategies to Adjust Positive End-Expiratory Pressure in Patients With ARDS-Reply. JAMA. 2019; 322(6): 580-2. PubMed Abstract | Publisher Full Text | Free Full Text

94. F Papazian L, Forel JM, Gacouin A, et al:: Neuromuscular Blockers in Early Acute Respiratory Distress Syndrome. N Engl J Med. 2010; 363(12): 1107-16. PubMed Abstract | Publisher Full Text | F1000 Recommendation

95. F National Heart, Lung, and Blood Institute PETAL Clinical Trials Network, Moss M, Huang DT, et al:: Early Neuromuscular Blockade in the Acute Respiratory Distress Syndrome. N Engl J Med. 2019; 380(21): 1997-2008. PubMed Abstract | Publisher Full Text | Free Full Text | F1000 Recommendation

96. F Slutsky AS, Villar J: Early Paralytic Agents for ARDS? Yes, No, and Sometimes. N Engl J Med. 2019; 380(21): 2061-3. PubMed Abstract | Publisher Full Text | F1000 Recommendation

97. Beitler JR, Sands SA, Loring SH, et al:: Quantifying unintended exposure to high tidal volumes from breath stacking dyssynchrony in ARDS: the BREATHE criteria. Intensive Care Med. 2016; 42(9): 1427-36. PubMed Abstract | Publisher Full Text | Free Full Text

98. F Chanques G, Kress JP, Pohlman A, et al:: Impact of ventilator adjustment and sedation-analgesia practices on severe asynchrony in patients ventilated in assist-control mode. Crit Care Med. 2013; 41(9): 2177-87. PubMed Abstract | Publisher Full Text | F1000 Recommendation

99. Akoumianaki E, Lyazidi A, Rey N, et al: Mechanical ventilation-induced reversetriggered breaths: a frequently unrecognized form of neuromechanical coupling. Chest. 2013; 143(4): 927-38. PubMed Abstract | Publisher Full Tex

100. F Pohlman MC, McCallister KE, Schweickert WD, et al.: Excessive tidal volume from breath stacking during lung-protective ventilation for acute lung injury.
Crit Care Med. 2008; 36(11): 3019-23.

PubMed Abstract | Publisher Full Text | F1000 Recommendation

101. Agrawal A, Matthay MA, Kangelaris KN, et al:: Plasma angiopoietin-2 predicts the onset of acute lung injury in critically ill patients. Am J Respir Crit Care Med. 2013; 187(7): 736-42.

PubMed Abstract | Publisher Full Text | Free Full Text

102. F Calfee CS, Delucchi K, Parsons PE, et al:: Subphenotypes in acute respiratory distress syndrome: latent class analysis of data from two randomised controlled trials. Lancet Respir Med. 2014; 2(8): 611-20. PubMed Abstract | Publisher Full Text | Free Full Text | F1000 Recommendation

103. Cressoni M, Chiurazzi $C$, Gotti M, et al:: Lung inhomogeneities and time course of ventilator-induced mechanical injuries. Anesthesiology. 2015; 123(3): 618-27. PubMed Abstract | Publisher Full Text

104. F Constantin JM, Jabaudon M, Lefrant JY, et al.: Personalised mechanical ventilation tailored to lung morphology versus low positive end-expiratory pressure for patients with acute respiratory distress syndrome in France (the LIVE study): A multicentre, single-blind, randomised controlled trial. Lancet Respir Med. 2019; 7(10): 870-80. PubMed Abstract | Publisher Full Text | F1000 Recommendation

105. Fan E, Dowdy DW, Colantuoni E, et al.: Physical complications in acute lung injury survivors: a two-year longitudinal prospective study. Crit Care Med. 2014; 42(4): 849-59.

PubMed Abstract | Publisher Full Text | Free Full Text

106. Kress JP, Hall JB: ICU-acquired weakness and recovery from critical illness. N Engl J Med. 2014; 370(17): 1626-35. PubMed Abstract | Publisher Full Text

107. F Schweickert WD, Pohlman MC, Pohlman AS, et al:: Early physical and occupational therapy in mechanically ventilated, critically ill patients: A randomised controlled trial. Lancet. 2009; 373(9678): 1874-82. PubMed Abstract | Publisher Full Text | F1000 Recommendation

108. F Goligher EC, Dres M, Fan E, et al:: Mechanical Ventilation-induced Diaphragm Atrophy Strongly Impacts Clinical Outcomes. Am J Respir Crit Care Med. 2018; 197(2): 204-13.

PubMed Abstract | Publisher Full Text | F1000 Recommendation

109. F Goligher EC, Brochard LJ, Reid WD, et al.: Diaphragmatic myotrauma: A mediator of prolonged ventilation and poor patient outcomes in acute respiratory failure. Lancet Respir Med. 2019; 7(1): 90-8. PubMed Abstract | Publisher Full Text | F1000 Recommendation

110. Goligher EC, Fan E, Herridge MS, et al.: Evolution of Diaphragm Thickness during Mechanical Ventilation. Impact of Inspiratory Effort. Am J Respir Crit Care Med. 2015; 192(9): 1080-8.

PubMed Abstract | Publisher Full Text

111. F Mauri T, Alban L, Turrini C, et al:: Optimum support by high-flow nasal cannula in acute hypoxemic respiratory failure: Effects of increasing flow rates. Intensive Care Med. 2017; 43(10): 1453-63. PubMed Abstract | Publisher Full Text | F1000 Recommendation

112. F Mauri T, Turrini C, Eronia N, et al:: Physiologic Effects of High-Flow Nasal Cannula in Acute Hypoxemic Respiratory Failure. Am J Respir Crit Care Med. 2017; 195(9): 1207-15.

PubMed Abstract | Publisher Full Text | F1000 Recommendation

113. Patel BK, Wolfe KS, Pohlman AS, et al.: Effect of Noninvasive Ventilation Delivered by Helmet vs Face Mask on the Rate of Endotracheal Intubation in Patients With Acute Respiratory Distress Syndrome: A Randomized Clinical Trial. JAMA. 2016; 315(22): 2435-41. PubMed Abstract | Publisher Full Text | Free Full Text

114. Beitler JR, Owens RL, Malhotra A: Unmasking a Role for Noninvasive Ventilation in Early Acute Respiratory Distress Syndrome. JAMA. 2016; 315(22): 2401-3. PubMed Abstract | Publisher Full Text | Free Full Text

115. Frat JP, Thille AW, Mercat A, et al:: High-flow oxygen through nasal cannula in acute hypoxemic respiratory failure. N Engl J Med. 2015; 372(23): 2185-96. PubMed Abstract | Publisher Full Text

116. Kangelaris KN, Ware LB, Wang CY, et al.: Timing of Intubation and Clinical Outcomes in Adults With Acute Respiratory Distress Syndrome. Crit Care Med. 2016; 44(1): 120-9.

PubMed Abstract | Publisher Full Text | Free Full Text 


\section{Open Peer Review}

\section{Current Peer Review Status:}

\section{Editorial Note on the Review Process}

Faculty Reviews are review articles written by the prestigious Members of Faculty Opinions. The articles are commissioned and peer reviewed before publication to ensure that the final, published version is comprehensive and accessible. The reviewers who approved the final version are listed with their names and affiliations.

\section{The reviewers who approved this article are:}

\section{Version 1}

\section{Bradford J. Smith}

University of Colorado at Children's Hospital Colorado, Aurora, CO, USA

Competing Interests: No competing interests were disclosed.

\section{Angela Rogers}

Department of Medicine, Division of Pulmonary and Critical Care Medicine, Stanford University School of Medicine, Stanford, CA, USA

Competing Interests: No competing interests were disclosed.

\section{Nuala J. Meyer}

University of Pennsylvania Perelman School of Medicine; Pulmonary, Allergy, and Critical Care Division, Philadelphia, PA, USA

Competing Interests: No competing interests were disclosed.

\section{Jason Bates}

Department of Medicine, Larner College of Medicine, University of Vermont, Burlington, USA

Competing Interests: No competing interests were disclosed. 
The benefits of publishing with F1000Research:

- Your article is published within days, with no editorial bias

- You can publish traditional articles, null/negative results, case reports, data notes and more

- The peer review process is transparent and collaborative

- Your article is indexed in PubMed after passing peer review

- Dedicated customer support at every stage

For pre-submission enquiries, contact research@f1000.com 